\title{
Exploring the Values of Local Wisdom as Sustainable Tourism Attractions
}

\author{
Rini Andari ${ }^{*}$, I Wayan Gede Supartha², I Gede Riana3, Tjokorda Gde Raka Sukawati ${ }^{4}$ \\ 1,2,3,4 Faculty of Economics and Business, Udayana University, Denpasar, Bali, Indonesia
}

\section{A R T I C L E I N F O}

Article history:

Received in revised form

5 September 2020

Accepted 18 October 2020

Available online 01

November 2020

Keywords:

Tourism, Local Wisdom

Value, Sustainable
Received 18 August 2020

\begin{abstract}
A B S T R A C T
Sustainable tourism is a concept that is aspired to be realized in the tourism industry so that natural and cultural resources can be preserved and enjoyed for generations to come. This research explores a variety of tourist attractions based on local wisdom values as an effort to create sustainable tourism. Kampung Banceuy is one of the traditional villages that has various values of local wisdom which is still preserved today and is able to attract many tourists. The method used in this research is an explorative qualitative approach. The data collection technique is done by direct observation, interviews, and documentation. Data analysis techniques were carried out in an interactive way and continued until completion, so that the data was saturated. The informants in this study were 9 people consisting of traditional leaders, communities, tourism managers, and tourists. The results showed that the value of local wisdom that can be a tourist attraction is village celebration events,
\end{abstract} cultural festivals, natural tourist attractions, and community life that has educational value. These various tourist attractions are not only oriented towards economic benefits but also act as a medium for the conservation of noble socio-cultural and environmental values as well as having educational value for tourists through the experience of tourism activities. The practice of the value of local wisdom that is still maintained is expected to always be passed on to the younger generation and can be of benefit to many parties, therefore this tourism activity always requires support from various parties.

Copyright (c) Universitas Pendidikan Ganesha. All rights reserved.

\section{Introduction}

Culture is the identity of a nation, for a country, culture-based tourism activities are not just for business fields but the most important thing is that they can become a medium to maintain cultural values. The value-based tourism activities of local wisdom are expected to balance globalization which often results in the ease with which outside cultures are incompatible with the value order in a region. Preservation and culture through tourism can be an effort to increase cultural resilience (Goeldner \& Ritchie, 2009; Jimura, 2011). Groups of people who still practice traditions inherited from their ancestors mean that they have local wisdom values that are able to survive against external cultures, have the ability to integrate elements of external culture into the original culture, and have the ability to adapt without leaving the noble values of their own culture. Local wisdom can be understood as cultural values, traditional ideas, and local knowledge that are wise, full of wisdom, good value, and virtuous (Darmadi, 2018; Sibarani, 2018). Local wisdom refers to knowledge that comes from community experiences and the accumulation of local knowledge found in communities, communities and individuals (Chaiphar et al., 2013). Local wisdom is obtained through experience and initiation as well as knowledge passed down from generation to generation (Singsomboon, 2014; Vitasurya, 2016).

The current environmental degradation has become a complex crisis and touches all aspects. This indicates a deterioration and ignorance of human behavior in managing the environment, maintaining and maintaining its sustainability. In addition, it cannot be denied that many young generations in Indonesia do not recognize the potential of natural and cultural wealth in their respective regions. Many of them feel 
unfamiliar with local cultural values that have noble values for character building for the younger generation. Such as the value of mutual cooperation, sincerity and concern for the natural environment.

Cultural tourism is a type of tourism activity in which the main motivation of visitors is to learn, discover, experience and consume real and intangible cultural products (tangible and intangible cultural attractions) in tourist destinations. Culture is often the most conserved component in rural areas and a valuable resource (MacDonald \& Jolliffe, 2003; Richards, 2018). The people of the Banceuy Traditional Village are one of the communities that live life in a rural atmosphere and until now they still maintain and maintain the values of local wisdom that were passed on by their ancestors. They live simply and maintain a balance between humans, the physical environment, and the transcendental environment. Local wisdom possessed by indigenous peoples can be used as a vehicle for education for tourists, especially those who come from very different cultures. As knowledge, local wisdom is found by certain local communities through a collection of experiences in trying and integrated with an understanding of the culture and nature of a place and is usually passed down from generation to generation by word of mouth (Darmadi, 2018).

The Banceuy community is also open to welcoming tourists who want to experience cultural experiences and enjoy the natural atmosphere of the countryside. Currently, Banceuy Traditional Village has become a rural tourist destination and compared to the surrounding area, Banceuy Traditional Village is visited by many tourists. Rural tourism is an activity that focuses on the consumption of rural experiences, culture, landscapes, and artifacts (Woods, 2011, 2016). This is considered to bring economic benefits to local communities as well as enhance the tourist experience with interaction opportunities between local people and tourists (Aref \& Gill, 2009; Khound, 2013). The natural beauty and cultural values of the indigenous people in Banceuy are a tourist attraction that can attract many people. Tourist attraction, both natural and man-made, is a core component of the tourism products of an area, without tourist attraction, there are no other tourism services (Benckendorff, 2001). The most ideal attractions are those that are rare, cannot be replicated, and are only available in certain destinations. Culture, heritage, and natural assets are a big part of a destination's product mix that helps give a destination a unique local character (Sinclair-Maragh, 2012; Vengesayi et al., 2009).

One of the cultures that are still practiced by the Banceuy people is in the form of ritual as a form of respect for nature. Until now, they have been able to maintain their natural beauty which has the potential to be developed as natural tourism. Nature-based tourism has experienced rapid growth in many countries and regions in recent years, brings economic benefits to local communities, and contributes to poverty alleviation (Balmford et al., 2009). Although nature-based tourism also raises some ecological problems (Hall \& Härkönen, 2006; Monz et al., 2013). Tourism activities cannot be separated from culture or community life, every tourist activity will occur cultural interactions between tourists and local communities. Tourists who visit a tourist destination will have the opportunity to learn and cultural learning can occur in them. The development of tourist attractions in rural areas is one of the strategic and long-term investment efforts to improve the quality of human resources and also the preservation of the natural environment and can provide economic benefits from tourist expenditure during tourist activities. This sector can be a tool for poverty alleviation, sustainable development, and an increase in the people's economy (Adom, 2019). Hence the local community should be the core players who provide and manage tourism products.

The tourism activities that have been running in the Banceuy traditional village can be a strategy to maintain the sustainability of cultural values, as a medium for introducing local history and culture to the wider community. Tourism activities can drive a creative economy which directly has the potential to provide added value to the income of its citizens. Culture and tourism are always closely related and local wisdom is part of culture (Darmadi, 2018; Richards, 2018). The uniqueness of cultural destinations is an attribute that differentiates it from other destinations (Ivanovic, 2008). Local wisdom as the foundation of sustainable development in rural tourism (Vitasurya, 2016). The concept of sustainability is concerned with meeting the needs of the current generation and enabling future generations to receive a high enough level of benefits to meet their own needs (Sangchumnong, 2018). Based on the background explanation above, the purpose of this study is to explore various tourist attractions based on local wisdom values as an effort to create sustainable tourism.

Subang Regency is one of the districts in West Java Province which has the potential to attract tourism, especially from cultural and natural diversity. Geographically, Subang Regency is adjacent to Bandung City as the capital of West Java Province. Geomorphologically, Subang Regency has varied landscapes in the form of mountainous, hill and lowland areas. The following is the number of tourist visits to tourist destinations in West Java and Subang Regency. Wangunharja Village or Sanca Village began to be developed as a tourist village with culture as the main attraction, due to the existence of Banceuy Village, which since 1999 has been used as an archaeological site by the local government as a 
Traditional Village. Banceuy Traditional Village can be used as cultural tourism because it has a strong local culture, distinctive culinary delights and customary laws. The value of local wisdom that is still held firmly by community groups in the area of Banceuy Village, Subang Regency, makes it able to survive against external cultures that can erode the values passed down from their ancestors. The manifestation of local wisdom values that exist in the Banceuy Traditional Village area can be grouped in the form of philosophical values from the history of the Banceuy Traditional Village, traditional ceremonial traditions, art, nature, special culinary delights, children's games, folk entertainment and procedures for building houses. The wisdom values that exist in the Banceuy Traditional Village are important to identify because they have noble values and can potentially provide attraction. However, the lack of support from various parties to develop tourism potential based on local wisdom in the Banceuy Village area causes all existing potential to be unable to be developed efficiently and sustainably, the lack of human resources and low knowledge and skills also causes cultural heritage to be gradually forgotten so that the emergence of a lack of concern for the existing culture. Unlike the case with the people of the Banceuy Traditional Village who live in a rural atmosphere, they still maintain their customs and rituals from generation to generation well. The massive flow of globalization that occurs cannot be completely avoided, this also occurs in the Banceuy Traditional Village which can be seen from changes in several aspects of life physically, but they do not change something they consider abstract, namely as values or customs that they have long had. . So with this, the people of Banceuy traditional village have a life guideline which is reflected in a slogan, namely "Ngindung ka Waktu Ngula ka Jaman" which means that on the other hand they do not reject change, but on the other hand for values or customs they cannot be contested and still be maintained. For this reason, researchers are interested in digging deeper into the value of local wisdom as a sustainable tourism attraction.

\section{Methods}

The target of this research is an understanding of a social phenomenon based on the perspective of the participants or the perspective of emic. This research design uses a qualitative approach, while the methods used are comparative studies (comparing the equations and differences of certain symptoms) and qualitative studies (measuring, displaying facts through survey techniques, tests, interviews, and questionnaires as well as correlation studies between one element. with other elements). This research was conducted in Banceuy Traditional Village using a qualitative approach, namely the type of research to reveal the meaning of the research results (Ritchie et al., 2005). Data were collected from words, pictures, and not numbers (Moleong, 2017) and taken from primary and secondary sources that were collected over a period of 10 months.

Research is conducted in natural conditions, is explorative in nature and the researcher is the key instrument. Explorative research is a research design that has the main objective of providing meaning and understanding of the problems at hand (Malhotra, 2004). Data collection techniques are carried out by participatory observation, namely a way to observe the behavior of a community by being directly involved in their activities (Creswell, 2017). Interviews were conducted with traditional leaders, communities, tourism managers, and tourists who are conducting tourism activities. The results of the data search are then processed qualitatively and described in descriptive form. The sampling process will continue until sufficient and accurate information is obtained to be analyzed in order to draw research conclusions. The validity of the data in this study used source triangulation with a series of qualitative data analysis according to the interactive model proposed by (Miles \& Huberman, 2014)which consists of the process of data collection, data reduction, data presentation and verification or drawing conclusions.

The data collection process was carried out throughout the research period, namely at the presurvey, at the time of the study, and even at the end of the study, then the compilation and uniformity of all forms of data obtained were carried out into one form of writing (script) to be analyzed. At the data reduction stage, the results of interviews and observations are converted into scripts to become summaries in order to make it easier for writers to focus on information then simplified. Presentation of data is the arrangement of data that is processed neatly in accordance with the focus of the observed research so as to allow for drawing conclusions. The conclusion stage is carried out based on the findings in the field and verification, namely receiving input that can be used to support the achievement of research objectives

\section{Results and Discussions}

Kampung Banceuy is located in the province of West Java, Indonesia which has tourism resources in the form of beautiful natural characteristics and unique socio-cultural life. Kampung Banceuy is 
designated as a traditional village by the Subang Regency government because it has succeeded in maintaining ancestral traditions that are full of local wisdom values. Kampung Banceuy is known as a village with 101 customs and is starting to be visited by many tourists who want to know and experience village life firsthand. The theory of the tourist attraction system, that the stronger an attraction, the greater its ability to attract tourists to a destination (MacDonald \& Jolliffe, 2003; R. Mill \& Morrison, 2015). The results of research exploration show that there are many values of local wisdom that actually exist in the Banceuy Traditional Village. The following are natural and cultural riches that contain local wisdom values that can attract many tourists and cultural researchers to visit Banceuy Traditional Village. Culture and nature can be used and utilized to support sustainable development in Southeast Europe (Ursache, 2015). Furthermore, cultural tourism in Palembang shows a role in preservation and conservation where cultural tourism creates jobs, new business opportunities and strengthens the local economy as well as improving the quality of life for residents and visitors (Lussetyowati, 2015). The role of cultural heritage in the development of effective sustainable destinations and culture plays an important pillar of environmental, social and economic sustainability (Mirza, 2016). Kampung Banceuy as a village that is known for its traditions that are still adhered to provides a number of attractions, both tradition, nature, traditional arts or special food. As a traditional village which is famous for its culture, traditions and rituals of traditional ceremonies are one of the tourist attractions in the Banceuy Traditional Village. One of them is that tourists can take part in an event held by Banceuy residents by being involved in a series of traditional ceremonial activities. The activities are all activities available at a destination and what consumers will do during their visit (Buhalis, 2000). Tourism activities are activities carried out around tourist destinations. Tourists who come to Banceuy Traditional Village can not only enjoy the traditions and rituals of traditional ceremonies during earth rituals or cultural festivals, but also enjoy the natural beauty of Leuwi Lawang and Curug Bentang which adds to the attractiveness so tourists can do activities such as hiking and trekking and even Due to its beautiful natural potential, Kompepar management has started offering camping and cycling activities.

\section{Earth Ruwatan Events and Cultural Festivals as Cultural Tourism Attractions}

Visitors from various circles and from various regions usually come to Banceuy Traditional Village during the Ruwatan Bumi event. There are many ceremonies that are still carried out by the people of the Banceuy Traditional Village, both those related to agriculture, the human life cycle and the religious system. Earth ruwatan event is held every year which attracts many tourists. Attraction is what first attracts visitors to a tourist area that presents different characteristics for each region (R. C. Mill, 2000). The peak event in this earth ruwatan is in the form of various arts and creativities from the residents of the Banceuy traditional village. The Ruwatan event can provide a memorable experience because tourists can enjoy various traditional rituals and traditional arts. There are factors that contribute to making the event special, namely uniqueness, hospitality, symbolism, festive spirit, theming, and authenticity (Getz, 2018). The value of uniqueness can be seen from the life of the people of the Banceuy traditional village which is different from the community in general because the people still maintain the values of the traditions or customs carried out by their ancestors. According to the residents of Banceuy, earth ruwatan is one of the ancestral mandates that must be carried out every year as a form of respect to always care for nature and the environment. This earth ruwatan event also has a sacred value because it is full of rituals and offerings to the Creator. Its implementation is tied to customary provisions, which must be carried out on the last Wednesday before the Islamic New Year.

Hospitality is the feeling of being accepted at a destination (R. C. Mill, 2000). This can be seen from the hospitality of the people of the Banceuy Traditional Village in welcoming anyone who visits. Guests who stay at residents' houses during the Ruwatan Bumi event usually get special food souvenirs that are usually served at the Earth Ruwatan event. This habit is what they call the term Ngabekelan which means providing provisions for guests who will return to their place of origin. In addition, the community also provides sincere assistance to the needs of tourists while in their village, such as providing services for eating and drinking.

The use of cultural symbols and traditions can be seen during traditional events. Banceuy residents use traditional clothing and art tools that can become their symbol or identity. The area of Banceuy village is also decorated with traditional decorations called sawen to enliven the atmosphere and become a symbol that in Banceuy there is a village celebration.

The festive spirit aspect can be felt from the community's expression that the earth ruwatan activity is an event that is eagerly awaited by the community. In fact, this event is held from citizen contributions. This activity is routinely held from generation to generation, giving rise to a spirit that has been ingrained since childhood. This event is a form of gratitude for the Creator and an arena for community gathering. This spirit can be seen from the atmosphere of the excitement of the event held so 
that tourists who come to this earth ruwatan event can feel the extraordinary spirit to always respect and maintain a culture that has high values. The earth ruwatan event raises an interesting cultural theme for tourists who want to witness Sundanese culture and traditions. Local culture is attractive because it is unique, which is different from other cultures. The Banceuy people creatively package this cultural theme so that it provides a memorable experience for tourists without changing sacred things such as traditional rituals.

Ruwatan Bumi cannot be carried out at any time because it is bound by customary rules. The Kompepar Traditional Village of Banceuy received a lot of information that many people could not attend the earth ruwatan event because it coincided with a working day. Therefore Kompepar facilitates this demand by holding a cultural festival event which is made similar to the Earth Ruwatan event on holidays. This festival was held to further introduce the culture of the Banceuy Traditional Village to many groups and the media to strengthen its identity as a traditional village. Organizing events can be used for destination promotion and also to form destination brands (Viol et al., 2018).

The cultural festival displays a variety of traditional arts that are mostly played by young people of Banceuy village as a means of introducing traditions passed down from their ancestors from generation to generation. Through this event, it is hoped that the young people of Banceuy Village can know and love their culture and will not feel foreign to their own culture. Tourism events are also a marketing strategy carried out by managers to attract tourists 'attention and to introduce tourist destinations as described by (Higgins, 2017)"event tourism is' the systematic planning, development and marketing of planned events as tourist attractions, and for their benefits to place marketing, image-making, and development ". The event is also explained by (Kotler et al., 2014) in the concept of a destination as a created market, that is, for a place that does not have natural or cultural potential even though it can become an attraction by holding an event, especially if the destination has cultural wealth that is packaged in the form of events it is believed to be able to. become an attraction that can bring in many tourists.

\section{The Attraction of Rivers and Waterfalls as Natural Tourist Attractions}

Apart from being famous for its cultural tourism, Banceuy Traditional Village also has amazing natural tourism potential. A river with a beautiful view called Leuwi Lawang and a waterfall called Curug Bentang. Currently, many visitors come when there are traditional activities or who deliberately come to enjoy nature by doing activities such as hiking. Leuwi Lawang is in the river that passes through Banceuy village. Leuwi means the deeper part of the river and Lawang means gate. There are two giant rock cliffs that flank the river so that it looks like a gate. Tourists can take pictures between the 2 giant, exotic rock cliffs. Curug Bentang is in the crevices of valleys and hills that are still green. Curug according to the Sundanese language means a waterfall while Bentang is a star. The waterfall is a place sacred to the Banceuy tradition. There are several things that must be obeyed when visiting and doing activities in this place, such as not speaking harshly. Visitors are advised to meet with community leaders before going to Curug Bentang and it is better if local residents can accompany the trip.

The authenticity of both places is still maintained so that it can provide relaxation and calm the mind. To get to this beautiful place, you have to go through a fairly steep road, but for those who like to climb mountains and like adventure traveling, this place can be a tourist destination of choice. Tourists who are usually interested in doing nature tourism activities to Leuwi Lawang and Curug Bentang are allocentric tourists who enjoy traveling by adventuring through beautiful nature with poor road conditions. Many signposts have also been damaged, and are not yet equipped with places to rest. Allocentric travelers also seek new destinations and are ready to take risks in new cultures and places (Burkart \& Medlik, 2009).

\section{Community Life and Rural Atmosphere as Educational Tourism}

The life of the people in the Banceuy Traditional Village is interesting and unique, they live in a rural atmosphere that still maintains their traditions from generation to generation and they are also open to welcoming tourists who want to experience cultural experiences and enjoy the rural atmosphere. Compared to the surrounding area, the traditional village of Banceuy is visited by many foreign and domestic tourists who continue to increase, both individually and in groups. The Banceuy people feel that nature is part of humans, and humans are part of nature, therefore they cannot claim to be the ruler. This can provide lessons to always respect the natural environment that provides human needs. This reason is why many educational institutions ranging from secondary education to higher education come to Banceuy traditional village with the aim of providing learning to students through direct experience from the community. Educational tourism is a tourism concept that combines the concept of non-formal education with tourism. Besides getting entertainment (recreation), tourists also get learning experiences with fun methods. Educational tourism is a program where participants in tourism activities take a tour in 
a certain place in a group with the main aim of gaining direct learning experiences related to the location visited (Rodger, 2013). A tourist activity undertaken by those who are undertaking an overnight vacation and those who are undertaking an excursion for whom education and learning is a primary or secondary part of their trip (Ritchie, 2003).

There is an educational institution that has an annual agenda bringing students and teachers to make observations in the Banceuy Traditional Village as part of the learning process. One of them was their arrival in 2019 to coincide with the holding of the "Banceuy Festival". They were in Banceuy Village for 5 days. The people of Banceuy Traditional Village welcomed the arrival of guests by holding traditional arts. They live in people's homes and have designed a fairly solid activity agenda. Kompepar explained that the students were introduced to the traditions of the life of the Banceuy people, they were involved with the daily activities of the local community such as farming and gardening. Students are also introduced to traditional arts including celempung, toleat and the typical culinary delights of the Banceuy Traditional Village.

Students from various universities also often come to the traditional village of Banceuy to collect data related to course assignments or final assignments. Banceuy Traditional Village is also frequently visited by researchers who are interested in exploring traditional values. A cultural researcher from Japan was present at the Ruwatan Bumi event and shared that he was interested in the traditions and culture that were still practiced by residents. He further explained that the traditions in the form of rituals, traditional ceremonies and traditional arts that are still maintained in the Banceuy Traditional Village show the closeness of the community to ancestors and nature so that they always live simply and in harmony with nature even though they cannot completely avoid the influence of outside cultures. However, he expressed his disapproval if the Banceuy Traditional Village was used as a mass tourist destination, according to him, tourists who come must be given an understanding to respect the prevailing values so that they can be maintained until the time to come. Educational tours are very beneficial for the community by participating in providing positive experiences and lessons so that anyone who goes on an educational trip can take lessons / lessons. Tourists benefit from gaining new knowledge and experiences in addition to the pleasures they feel at tourist destinations. Therefore, in educational tourism, it is necessary to apply the principle called (Sharma, 2015) as 3E consisting of environmental factors, engagement, and exploration.

Environmental factors, are the physical environment and the social environment. The traditional village of Banceuy has a physical environment in the form of a beautiful natural atmosphere, a clean environment, far from pollution and garbage and a social environment in the form of community attitudes in receiving and serving guest visits, friendly and polite attitudes, and community attitudes that create a sense of security and comfort. for tourists. The people of Banceuy traditional village realize that their village is a cultural tourism destination, they make it happen by making a Sapta Pesona signpost in front of the Banceuy Traditional Village Kompepar Secretariat to provide assurance for tourists who come. The participation factor (engagement), namely the involvement of tourists in every activity which is the core of the learning process. In educational tours, tourists participate actively like a number of students when they are in Banceuy Traditional Village, they take part in the daily activities of Banceuy residents such as going to the garden or to the rice fields they are involved in community activities so that they are able to absorb the knowledge and messages conveyed, so they can practice in daily life. Besides that, they also went hiking to Curug Landscape and Leuwi Lawang, they could enjoy the natural beauty created by God which could cause gratitude for all the gifts and greatness of God Almighty.

Exploration can provide direct learning to tourists about a place. Tourists who carry out activities in the Banceuy Traditional Village can explore and dig up the information they need, such as what students do for their final assignments and researchers by direct observation. Usually before carrying out exploration activities, briefing activities are first carried out by the tourism village manager. Briefing is carried out to provide basic knowledge, while exploration will provide deeper knowledge and understanding through experiences gained in the field.

Apart from being seen from the element of tourist attraction, a tourist destination, especially cultural and natural tourist destinations, must be able to fulfill the elements of other tourist destinations because a tourist village is a form of integration between attractions and supporting facilities that are presented in a structure of community life that integrates with the traditional procedures applies. Destination elements consist of attractions, accessibility, amenities, available packages, activities, and ancillary services (Buhalis, 2000). The traditional village of Banceuy has a village road that can be accessed by motorbikes and cars. Even though it is relatively easy to reach, access to the Banceuy Traditional Village is not like a mass tourist destination that can be reached by public transportation or bus. The road width that is not too big is a problem when there are vehicles from the opposite side. At some points there are steep, uphill, and downhill road conditions so tourists have to be careful. The 
journey to the Banceuy Traditional Village will provide its own experience because it is located far from the city center. Tourists must pass through winding roads with routes through residential areas, tea gardens, pineapple gardens and rice fields. Along the way, you will see a beautiful expanse of natural scenery that will be part of the experience of your tour. Directions are only available at a few points in the form of small signposts with very simple writing and some of them have been damaged, so tourists often have to ask the residents. However, at this time with the help of Google Map, tourists will be given directions to arrive without getting lost. Arriving at the location, tourists will finally be greeted by a simple gebang with the words "Welcome to Banceuy Traditional Village".

The need for amenities is not an attraction, but if there is a lack of amenities in a destination it will be avoided by tourists. The management provides for the needs of tourists while carrying out tourism activities in Banceuy Traditional Village. There is a parking space for tourists who bring private vehicles and for tourists who stay overnight, a homestay is provided, they stay at the homes of Banceuy residents mingling with the local community and enjoying the daily life of the residents there. Likewise for food and beverage needs are usually provided by the homestay owner with a menu that can be tailored to the wishes of guests. For tourists who do hiking and trekking in nature tourism, the manager accompanies and provides tour guides. Entertainment facilities are also available for those guests who want to enjoy typical Banceuy arts such as cilempungan and kaulinan barudak (typical Banceuy games). Banceuy typical souvenirs can be obtained by ordering in advance such as the typical banceuy ranginang katumiri or kue one. For tourists who come during a cultural festival or a celebration of the earth's ruwatan, they will get a typical banceuy souvenir easily without having to order because many local residents also sell their wares when the two events are held.

There are many activities that tourists can do while in Banceuy Traditional Village. One of them is that tourists can take part in an event held by Banceuy residents by being involved in a series of traditional ceremony activities. Activities are all activities available at a destination and what consumers will do during their visit. Tourism activities are activities carried out around tourist destinations. Tourists can also enjoy the beauty of nature and can do activities such as hiking and trekking even because of its beautiful natural potential (Buhalis, 2000), the Kompepar manager / party has started offering camping and cycling activities. Some student tourists carry out educational tourism activities by following the daily activities of Banceuy residents such as farming and gardening. They can also do activities with the children and youth of Banceuy residents by playing typical Banceuy games such as Gusur Upih, crank, jajangkungan, miruha, gatrik, and nyumpit. The various activities that tourists can do are a reflection of the wealth of resources a tourist destination has that can provide a unique experience and become a motivator for tourists to visit a destination.

Regarding tourism destination management agencies, the Banceuy Traditional Village is managed by Kompepar, whose members are the Banceuy indigenous people under Bumdes Desa Sanca and the government of Ciater and Subang districts which supports the development of the Banceuy Traditional Village as a cultural site and a cultural tourist attraction. Ancillary service is an organization that facilitates and develops tourism as well as for tourism marketing in a destination concerned (Sugiama, 2011). So far, the management has tried to introduce the Banceuy traditional village through various promotional channels including through social media which are packaged creatively, although not yet well structured. One of the support from the Subang Regency Government is also evident from the promotional efforts carried out by including the Earth Ruwatan event in the event calendar of West Java and Subang Regency.

Tourists can order tour packages made with a tailor made system, namely tour packages that are flexible in nature according to the wishes and needs of tourists. Such as including a combination of cultural tourism, nature tourism, and educational tourism. Kompepar also provides tour packages in the form of ready made tours for tourists who do not want to be involved in the itinerary arrangement, these tourists usually entrust the manager to arrange the activities while they are there. The existence of a tour package that combines several attractions or events in one time can make it easier for tourists to experience and experience various attractions in one time.

\section{Conclusion}

The values of local wisdom extracted from the Banceuy Traditional Village in the form of traditions, customs, traditional arts, and natural preservation are important things that are able to provide tourist attraction. Its uniqueness can be seen from the way of life and expertise passed on from their ancestors in terms of farming and preserving nature, which is often manifested in ceremonial forms and traditional ceremonies. Cultural tourism travel activities can provide experiences to tourists by engaging directly with the local community, seeing the way of life and culture of the people in their group so that it allows a desire to learn about this culture, and they not only get entertainment but also gain value in the form of 
new experiences and knowledge. Therefore tourism activities cannot be separated from culture or community life because in every tourist activity there will be cultural interactions between tourists and local communities. Comfort and safety are the main things that tourists pay attention to, so the elements that must be considered in tourist destinations other than tourist attraction as the main elements of accessibility, amenities, available packages, activities, and ancillary services are elements that form tourist destinations that are without good existence. can cancel tourists to carry out tourist activities at these destinations. Efforts in developing a tourist village cannot be separated from the synergistic cooperation between the parties called the involvement of the pentahelical element consisting of elements of society, government, business actors in the tourism sector, academics, and the media. The spirit of nature and culture conservation is the main priority and must be held and carried out jointly by all parties involved in developing a tourism village. By maintaining harmony between people's lives, the natural and cultural environment, it can bring economic benefits. Coordination between interested parties is needed to achieve the goal of developing a sustainable tourism village.

\section{References}

Adom, D. (2019). The place and voice of local people, culture, and traditions: A catalyst for ecotourism development in rural communities in Ghana. Scientific African, 6. https://doi.org/10.1016/j.sciaf.2019.e00184

Aref, F., \& Gill, S. S. (2009). Rural tourism development through rural cooperatives. Nature and Science, $7(10)$, 68-73. https://www.researchgate.net/profile/Sarjit_Gill/publication/305397865_Rural_tourism_develop ment_through_rural_cooperatives/links/5f3cf0c0a6fdcccc43d32dac/Rural-tourism-developmentthrough-rural-cooperatives.pdf

Balmford, A., Beresford, J., \& Green, J. (2009). A global perspective on trends in nature-based tourism. PLoS Biol, 7. https://doi.org/10.1371/journal.pbio.1000144

Benckendorff, P. (2001). Planning For The Future A Study of Australian Tourist Attractions. James Cook.

Buhalis, D. (2000). Marketing the Competitive Destination of the Future. Tourism Management, 21(1), 97116. https://doi.org/10.1016/S0261-5177(99)00095-3

Burkart, A., \& Medlik, S. (2009). Tourism: Past, Present and Future. Heinemann.

Chaiphar, W., Sakolnakorn, P. N., T., \& Naipinit, A. (2013). Local Wisdom in the Environmental Management of a Community: Analysis of Local Knowledge in Tha Pong Village, Thailand. Journal of Sustainable Development, 6(8), 16-25. https://www.cabdirect.org/cabdirect/abstract/20143030338

Creswell, J. W. (2017). Research Design. Pustaka Pelajar.

Darmadi, H. (2018). Educational Management Based On Local Wisdom (Descriptive Analytical Studies Of Culture Of Local Wisdom In West Kalimantan). Journal of Education, Teaching And Learning, 3(1), 135-145. https://www.learntechlib.org/p/209101/

Getz, D. (2018). Event Management \& Event Tourism (2nd ed.). Cognizant Communication Corporation.

Goeldner, R. C., \& Ritchie, B. J. R. (2009). Tourism: Principles, Practices, and philosophies (11th ed.). John Willey and Son.

Hall, C. M., \& Härkönen, T. (2006). Lake Tourism: An Integrated Approach to Lacustrine Tourism Systems. Channel View Press.

Higgins, F. (2017). Event Tourism and Event Imposition: A Critical Case Study From Kangaroo Island, South Australia. Journal Tourism Management, 64, 73-86. https://doi.org/10.1016/j.tourman.2017.08.002

Ivanovic, M. (2008). Cultural tourism. Juta.

Jimura, T. (2011). The impact of world heritage site designation on local communities - A case study of Ogimachi, Shirakawa-mura, Japan. Tourism Management, 32(2), 288-296. https://doi.org/10.1016/j.tourman.2010.02.005.

Khound, J. M. (2013). Constraints and prospects of rural tourism development: An overview of tourism in Shyamgaon of Titabor of Jorhat, District (Assam). Journal of Tourism and Hospitality Management, 


\section{1(1), 27-31. http://jthmnet.com/journals/jthm/Vol_1_No_1_December_2013/4.pdf}

Kotler, P., Bowen, J. T., \& Makens, J. C. (2014). Marketing For Hospitality And Tourism (6th ed.). Pearson International.

Lussetyowati, T. (2015). Preservation and Conservation through Cultural Heritage Tourism. Case Study: Musi Riverside Palembang. Procedia - Social and Behavioral Sciences, 184, 401-406. https://doi.org/10.1016/j.sbspro.2015.05.109

MacDonald, R., \& Jolliffe, L. (2003). Cultural rural tourism: Evidence from Canada. Annals of Tourism Research, 30(2), 307-322. https://doi.org/10.1016/S0160-7383(02)00061-0

Malhotra, N. K. (2004). Marketing Research: An Applied Orientation (4th ed.). Pearson Education Inc.

Miles, M. ., \& Huberman, A. M. (2014). Qualitative Data Analysis, A Methods Sourcebook (3rd ed.). Sage Publications.

Mill, R. C. (2000). Tourism The International Bussines. Raja Grafindo Persada.

Mill, R., \& Morrison, A. (2015). The Tourism System, An Introductory Text. Prentice Hall Inc.

Mirza, N. (2016). The Impact of Cultural Heritage on Sustainable Tourism Development: The Case of Bergama (Pergamon). Journal of Tourism and Gastronomy Studies, 4(3), 60-66. https://www.jotags.org/2016/vol4_issue3_full_issue.pdf\#page=72

Moleong, J. (2017). Metodologi Penelitian Kualitatif. Pt Remaja Rosdakarya.

Monz, C. A., Pickering, C. M., \& Hadwen, W. L. (2013). Recent advances in recreation ecology and the implications of different relationships between recreation use and ecological impacts. Frontiers in Ecology and the Environment, 11, 441-446. https://doi.org/10.1890/120358

Richards, G. (2018). Cultural tourism: A review of recent research and trends. Journal of Hospitality and Tourism Management, 36, 12-21. https://doi.org/10.1016/j.jhtm.2018.03.005

Ritchie, B. W. (2003). Managing Educational Tourism. Channel View Publications.

Ritchie, B. W., Burns, P., \& Catherine. (2005). Tourism Research Methods:Integrating. Theory with Practice Palmer. CABI Publishing.

Rodger. (2013). Leisure, Learning and Travel. Journal of Physical Education, 69(4), 28-31. https://doi.org/10.1080/07303084.1998.10605532

Sangchumnong, A. (2018). Development of a sustainable tourist destination based on the creative economy: A case study of Klong Kone Mangrove Community, Thailand. Kasetsart Journal of Social Sciences, 40(3). https://so04.tci-thaijo.org/index.php/kjss/article/view/242302

Sharma, A. (2015). Educational Tourism : Strategy for Sustainable Tourism Development with reference of Hadauti and Shekhawati Regions. Journal of Knowledge Management, Economics and Information Technology, 5(4), 1-17. https://ideas.repec.org/a/jbu/jbeitt/1425.html

Sibarani, R. (2018). Batak Toba society's local wisdom of mutual cooperation in Toba Lake area: a linguistic anthropology study. International Journal of Human Rights in Healthcare, 11(1), 40-55. https://doi.org/10.1108/IJHRH-08-2017-0035

Sinclair-Maragh, G. (2012). Denbigh Showground: a potential "agri-cultural" attraction concept for tourism in Jamaica. Emerald Emerging Markets Case Studies, 2(8), 1-17. https://doi.org/10.1108/20450621211317654

Singsomboon, T. (2014). Tourism Promotion And The Use Of Local Wisdom Through Creative Tourism Process. IJBTS International Journal of Business Tourism and Applied Sciences, 2(2), 32-37. http://www.ijbts-journal.com/images/column_1356587250/20012920Termsak20Singsomboon_ Vol 2 No2.pdf

Sugiama, A. G. (2011). Ecotourism: Pengembangan Pariwisata berbasis konservasi alam. Guardaya Intimarta.

Ursache, M. (2015). Tourism-significant driver shaping a destinations heritage. Procedia - Social and Behavioral Sciences, 188, 130-137. https://doi.org/10.1016/j.sbspro.2015.03.348

Vengesayi, S., Mavondo, F. T., \& Reisinger, Y. (2009). Tourism destination attractiveness: attractions, 
facilities, and people as predictors. Tourism Analysis, 14(5), 621-636. https://doi.org/10.3727/108354209X12597959359211

Viol, M., Todd, L., Theodoraki, E., \& Anastasiadou, C. (2018). The role of iconic-historic commemorative events in event tourism: Insights from the 20th and 25th anniversaries of the fall of the Berlin Wall. Tourism Management, 69(2), 246-262. https://doi.org/10.1016/j.tourman.2018.06.018

Vitasurya, V. R. (2016). Local Wisdom for Sustainable Development of Rural Tourism, Case on Kalibiru and Lopati Village, Province of Daerah Istimewa Yogyakarta. Procedia - Social and Behavioral Sciences, 216, 97-108. https://doi.org/10.1016/j.sbspro.2015.12.014

Woods, M. (2011). Rural. Routledge.

Woods, M. (2016). Reconfiguring places-wealth and the transformation of rural areas. Handbook on wealth and the super-rich. https://doi.org/10.4337/9781783474042 